\title{
II. Meşrutiyet Döneminde Fener Rum Ortodoks Patrikhanesi'nin Siyasî Faaliyetleri
}

\author{
Dr. Emruhan YALÇIN*
}

\begin{abstract}
$\ddot{O}_{z e t}$

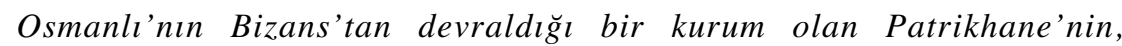
Imparatorluğun yükselme ve duraklama dönemlerinde "millet sistemi” esasina dayanan siyaseti gereği bazl yetkilerle donatllarak Rum tebaa üzerinde etkinleştirildiğini görmekteyiz. Imparatorluğun gerileme ve yeni Türk Devleti'nin Milli Mücadele dönemlerinde milliyetçilik akımlarından etkilenen ve diş güçlerin desteğini de alan Patrikhane; Megali İdea için çok önemli bir dönüm noktası olan Yunanistan'ın bă̆ımsız bir devlet olma düşüncesini hayata geçirmiş, kurulduğu günden I. Dünya Savaşı'nın sonuna kadar topraklarının katlanarak genişletilmesi yolunda klsa sürede çok mesafe kat ederek Bizans'ın yeniden canlandırllması amacıyla yürütülen her faaliyeti ya organize etmiş, ya desteklemiş, ya da faaliyeti bizzat icra etmiştir.

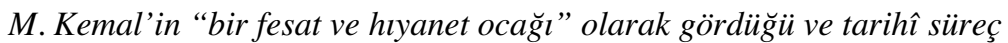
içerisinde devlet ve millet aleyhine faaliyetleri göz önünde bulundurulan Patrikhane’nin Lozan görüşmeleri sırasında Misak-ı Millî sınırları dışına çıkarılmak istenmesine ră̆men, Hristiyan Bloğun direnci ve israrı nedeniyle başarılı olunamamıştır. Türkiye Cumhuriyeti sınırlart içinde kalan 1500-2000 Ortodoks Rum tebaanın sadece dinî vecibelerini yerine getirmek üzere topraklarımız üzerinde kalmasına izin verilen Rum Patrikhanesi, bugün demokratik ve laik Türkiye Cumhuriyeti'nin köklü bir kurumu olarak diğer Türk kurumları gibi Devletin istiklali ve Cumhuriyetin bekası için üzerine düşen görevi yapmak zorundadır.
\end{abstract}

Anahtar Kelimeler: II. Meşrutiyet, Patrikhane, Metropolit, Ittihat ve Terakki, Yunanistan.

* Bilkent Üniversitesi, Yarı Zamanlı Öğretim Görevlisi, e-posta: eyalcin@bilkent.edu.tr 


\title{
The Phanar Greek Patriarchate During the Second Constitutional Period
}

\begin{abstract}
The Patriarchate, which was inherited by the Ottomans from Byzantium, was endowed with certain political rights over the Greek subjects during the "nation system" policy of the Empire. With the support of other states and nationalism during the Decline of the Empire and Turkish War of Independence, the Patriarchate was essential for the establishment of Independent Greece along with its Magalia Idea. From the Greek independence to the end of the First World War, the Patriarchate helped, organized and supported every activity to expand Greece and to restore Byzantium.

Because of its activities against the state and nation Mustafa Kemal had seen it as a "society of sinister activities and betrayal". The Patriarchate was to be expelled from the Misak- $\mathrm{Milli}$ borders in the Treaty of Lausanne, but this could not succeed because of pressures from the Christian Bloc. The Patriarchate was allowed to stay inside the Turkish Republic only to fulfill its religious activities for 1500-2000 Orthodox congregation, and today it is a fundamental foundation of the democratic and secular Turkish Republic, which has to support for the stability of the State, like the other Turkish foundation.
\end{abstract}

Key Words: The Second Constıtutional Period, the Patriarchate, the Metropolitan, the Committee of Union and Progress, Greece.

\section{GíRIŞ}

Fransız Devrimi’nin milliyetçi ve özgürlükçü fikirleri, batılı devletlerin çıkarları ile birleştirilerek Balkan milletleri arasında yayılıyordu. Değişen tarihsel koşullar Osmanlı Devleti’nin aleyhine çalışıyordu. Öte yandan, imparatorluğun kaçınılmaz çöküşünü batılılaşma çareleri ve yapılan 1slahatlar durduramıyordu. Balkanlarda esen bağımsızlık ve özgürlük rüzgârına ne Padişah ne de Patrik karşı koyabildi. ${ }^{1}$ Bir zamanlar Avrupa kıtasında hâkimiyet kurmuş olan Müslüman Türklerin Avrupa'dan sürülüp atılmalarının vakti gelmişti. Batı bu hedefini, Balkan Savaşları ve Birinci Dünya Savaşı'nda büyük ölçüde gerçekleştirdi.

Batılıların "Şark Meselesi” adını verdiği, gerçekte "Türk Meselesi” olan ve Türklerin Avrupa'dan, hatta Anadolu'dan sürülerek kendi Öz Yurtlarına yani Orta Asya’ya gönderilmesi bu dönemde gerçekleştirilmeye çalışılmıştır.

${ }^{1}$ Chavles A. Frazee, The Orthodox Church and Independent Greece 1821-1852, Cambridge, 1969, s.14.

${ }^{2}$ Yusuf Hikmet Bayur, Türk Inkılap Tarihi, Cilt II, Kısım III, Türk Tarih Kurumu Yayınları, Ankara, 1951, s.253-4, 274-5. 
Avrupalılar, Türklerin üstün ve güçlü olduğu birinci safhadaki (1071-1683) Türk taarruzlarına karşı koyamayarak; Türkleri Anadolu'ya sokmamak, Anadolu'da durdurmak, Rumeli'ye geçirmemek, Avrupa içlerine ilerlemesini durdurmak olan hedeflerine ulaşamamıştır. Ancak, Türklerin Viyana mağlubiyetinden sonra başlayan ve ikinci safha olarak kabul edilen devrede; Balkanlarda isyanlar çıkararak Hristiyan milletlerin bağımsızlıklarını kazanmalarını sağlamak, Türkleri Balkanlardan tamamen atmak, İstanbul'u Türklerin elinden almak, Anadolu'da bulunan Hristiyan azınlıklar lehine ıslahatlar yaptırmak ve istiklallerine kavuşturmak, Anadolu'yu paylaşarak Türkleri buradan da çıkartmak olarak özetleyebileceğimiz olayları yakın geçmişimizde teker teker yaşadık. İtilaf Devletleri, 30 Ekim 1918'de Osmanlı Hükûmeti'ne imzalattırdıkları Mondros Mütarekesi'nin yedinci maddesine dayanarak, yapılan antlaşmanın meclislerinde onaylanmasını dahi beklemeden, 6 Kasım'dan itibaren memleketimizi işgal etmeye başladılar. Çünkü bu, Batı Dünyası'nın eline geçmiş en büyük fırsattı. Ne var ki, Batılılar bu sefer de hedeflerine ulaşamamışlardır. Fakat onlar hedeflerine ulaşmak için her yolu denemektedir. Silah gücü ile yenemedikleri Türkleri, bu sefer içten çökerterek amaçlarına ulaşmak istemektedirler. "Şark Meselesi", tarih kitaplarımızda bu şekilde iki safhaya ayrılmaktadır." Savaşlar sonrası değişen dünya koşulları çerçevesinde, Batı Dünyası'nın Türkiye'ye karşı geliştirdikleri savaşsız, silahsız politikayı siyaset sahnesine sürmeleriyle, "Şark Meselesi”nin üçüncü safhasına girildiğini gözlemlemekteyiz. Asıl tehlikelisi de bu safhadır. Çünkü kimin dost, kimin düşman olduğunu fark edemeden Anadolu topraklarının da elimizden çıkabileceğini düşünmek çok da uzak bir ihtimal değildir. $\mathrm{Bu}$ son safhada, bir yandan $\mathrm{AB}$ sürecinde Türkiye'ye dikte ettirilen hususları, bir yandan da merkezinde Patrikhanenin oturduğu Ortodoks dinine mensup devletler tarafından Türkiye'nin "Ortodoks çemberi içine alınması" ve Türkiye'ye karşı bir "Ortodoks İttifakı" kurma gayretleri, aynı aktörler tarafından aynı mekânda tarihte uygulanan oyunların tekrarlandı ̆̆ının göstergesidir. Bunun asıl amacı da Anadolu topraklarından Türklerin ve Müslümanlığın sürülerek çıkarılmasıdır. ${ }^{4} 1000$ yıllık Şark Meselesinin günümüzdeki versiyonu olan AB, Türkiye'yi bölerek hazmedilebilir şekle getirme planlarını gerçekleştirmeye çalışmaktadır. Bu nedenle, Türk Milleti'nin tarihten ders alarak gerekli tedbirleri geliştirmesi ve olaylarda ön alması gerekmektedir. Bir Truva Atı misali "Misak-ı Millî" sınırları içerisinde bırakılan Patrikhanenin, "Megali İdea" çerçevesinde çizilen yolda yavaş yavaş, fakat emin adımlarla nasıl ilerlediğini görmek için yakın tarihimizdeki olayları iyi

\footnotetext{
${ }^{3}$ Hacettepe Üniversitesi Atatürk İlkeleri ve İnkılâp Tarihi Enstitüsü Öğretim Üyeleri, Atatürk ve Türkiye Cumhuriyeti Tarihi, Siyasal Kitabevi, Ankara, 2004, s.56.

${ }^{4}$ Emruhan Yalçın, Atatürk Türkiye'sinde Ekümenik Ortodoks Patrikhanesi ve Bizans Projesi, Siyasal Kitabevi, Ankara, 2008, s.343.
} 
tahlil ederek yorumlamak gerekmektedir. Yeni çıkarılan "Vakıflar Yasası" ile hedefine bir adım daha yaklaşan Patrikhane gözünü hedefinden bir saniye dahi ayırmamaktadır.

\section{Trablusgarp Savaşı Sırasında Patrikhanenin Faaliyetleri}

Osmanlı hâkimiyeti altında varlığını muhafaza etmeye çalışan Patrikhane, Megali İdea doğrultusundaki isteklerini daha da ileri götürerek, Rumeli bölgesindeki tüm Ortodoks tebaayı Rumlaştırma, kiliseleri ve mektepleri de Rum kilisesi ve mektebi haline getirme gayretlerini artırıyordu. Bu durumun Osmanlı Devleti'ne de tesir edeceğinin farkında olan Babıali, Ortodoks unsurlar arasında kilise anlaşmazlıklarından doğabilecek büyük bir karışıklığın önüne geçmek için; 3 Temmuz 1910 tarihinde, halk arasında "Kiliseler Kanunu" olarak adlandırılan "Rumeli'de kain münazaun-fih kilise ve mektepler hakkındaki kanun"u, Sultan Mehmet Reşat ve Sadrazam İbrahim Hakkı'nın da onaylamalarından sonra yürürlüğe soktu. 11 maddeden meydana gelen kanun kısaca; kilise ve mekteplerin paylaşımının nüfus yoğunluğuna göre olacağı, eşit dağılımlı mahallerde halkın kilise ve mekteplerden birisini tercih etmesinin gerektiği, yeni kilise ve mektep inşası için nakdi yardımın hükûmet tarafından yapılacağı ve uygulamanın da Dâhiliye ile Adliye Nezaretleri tarafından yapılması hususlarını içermektedir. Kiliseler Kanunu, devlete maddi olarak oldukça fazla bir yük getirmiş olmasına rağmen, Patrikhane devletin katkılarıyla yeni kilise ve mektep yapılması meselesine şiddetle karşı çıktı. Çünkü Patrikhanenin halk üzerindeki etkinliğinin ve Bulgarların kendilerine olan bağlılığının azalacağını düşünüyordu. ${ }^{5}$

Rumlar, Trablusgarp Savaşı süresince Patrikhaneden aldığı talimatlar gereği "Kiliseler Kanunu"nu kaldırtabilecekleri ümidiyle Rumeli'nin birçok yerinde bu kanun ile sözde bazı imtiyazlarının ellerinden alındığına dair iddialarla gösteriler yapmaya başladılar. $\mathrm{Bu}$ gösterilerin amacı Trablusgarp'te savaş ile uğraşırken Hükûmeti zor durumda bırakmak ve Patrikhane için arzu ettikleri statüyü elde etmekti. Patrikhaneye bağlı metropolitler de aynı çaba içinde idiler. Bunlardan Vidin Rum Metropoliti, çalışanlarının bir kısmının görevlerine son vererek, yerlerine yardım ve yataklık yapmaları için çetelerden bazılarını yerleştirdi. Bunlar askerî elbiseler giyerek dolaştıklarından, hem güvenlik açısından tehlike arz ediyorlar hem de o çevrede yaşayanlar rahatsızlık duyuyordu. ${ }^{6}$

İzmir Metropoliti Hrisostomos'un, savaş şartları ile birlikte olumsuz davranışlarında artış görüldü. Metropolit Hrisostomos'un, 23 Nisan 1911

\footnotetext{
${ }^{5}$ Bülent Atalay, Fener Rum Ortodoks Patrikhanesi'nin Siyasi Faaliyetleri (1908-1923), Tarih ve Tabiat Vakfı (TATAV) Yayınları, İstanbul, 2001, s.54.

${ }^{6}$ Selânik ViIâyeti'nden Dahiliye Nezareti'ne gönderilen 15 Şubat 1329/27 Şubat 1911 tarihli tahrirat: BOA, Dahiliye Nezareti Mütenevvia, Nu. 54/3.
} 
tarihinde İzmir Metropolithanesi'nde Ayayorgi Yortusu münasebetiyle yaptığ1 konuşmalar ve Rumları Türklere karşı açıkça kışkırtması, Aydın Valisi Nazım Paşa'yı bir takım tedbirler almaya zorladı. Hrisostomos'un daha önceki olumsuz davranışlarını da göz önünde bulunduran Vali, kendisini vilâyet azalığından uzaklaştırdı. Yıllarca Türk milletinin kadirşinaslığından istifade ettikleri halde, bazı Rumların, savaş sebebiyle oluşan olağanüstü hali açıkça istismar etmeleri Vali Nazım Paşa'yı çok öfkelendirdi. Bu öfke ve heyecanını önleyemeyen Nazım Paşa, Rum Cemaatı İhtiyar Meclisi azalarının hepsinin ihtilalci olduklarını ifade etti. Valinin bu açıklamalarından sonra Meclis-i Mebusan'da İzmir mebusu Pavlo Karalodi Efendi bu suçlamaların çok ağır olduğunu ve kabul edilemeyeceğini belirterek, Rumları savundu. Fakat olayların üzerinden çok kısa bir süre geçmesine rağmen, Vali Nazım Paşa'nın ne kadar haklı olduğu bir kez daha ortaya çıktı. İzmir'de 8 Mayıs 1911 tarihinde Yunan kraliyet ailesinin özel günleri münasebetiyle İzmir Metropolithanesi'nde yapılan ayinden sonra bir tören düzenlendi. Bu törene Yunanlılar ile yerli Rumların ve özellikle Osmanlı Rum mektebi öğrencilerinin katılımları sağlandı. Tören sırasında Yunan Konsolosluğu önüne kadar yüründü ve burada devam eden sevinç gösterilerinde Yunan bayrakları açılarak, Türkler tahrik edilmeye çalışıldı. ${ }^{7}$

Gayrimüslimlerin yaptıkları ve Avrupa Devletlerinin Osmanlı Devleti'ne karşı uyguladıkları baskı politikasından bıkan halk, 21 Eylül 1911 tarihinde İkindi namazından sonra hiçbir plan ve program yapılmadan Ayasofya Camii avlusunda toplandı. Burada Aydın Mebusu Âbidin Efendi, mebusluk sıfatını dikkate almadan çok muzdarip durumda bulunan milletin bir ferdi olarak içinden geldiği gibi yine milletin sstırabını dile getiren bir konuşma yaptı. Abbidin Efendi'nin konuşmasından sonra alınan karara bağlı olarak; İngiltere Kralı'na, Almanya ve Avusturya İmparatorlarına protesto amacıyla telgraflar çekildi. Çekilen bu telgraflar, Avrupa basınında geniş yankı uyandırdı. Her şeyi Babıâli'ye karşı baskı unsuru olarak kullanmayı adet haline getiren Avrupa Devletleri, Ayasofya Camii önünde yapılan bu gösterileri haklı çıkarırcasına, kendilerine milletin fertlerinin çektiği telgrafların nezaket sınırlarını zorladığı iddiası ile Babıâli’yi, yapılan gösterilere engel olmamakla suçladı ${ }^{8}$

\section{Balkan Savaşlarında Patrikhanenin Faaliyetleri}

1829'da Yunanistan'ın bağımsızlığını elde etmesi ile başlayan genişleme süreci, 1897 Osmanl1-Yunan Harbinden Yunanistan'ın hezimete uğrayarak çıkmasından sonra bir müddet için durmuştur. Olabildiği kadar Yunan halkını içine alarak Yunan Devletini genişletmek ve Akdeniz'de

${ }^{7}$ Aydın Vilâyeti'nden Dâhiliye Nezareti'ne gönderilen 26 Nisan 1327/9 Mayıs 1911 tarihli tahrirat: BOA, Dâhiliye Hukuk, Nu. 14-1/22.

${ }^{8}$ Hariciye Nezareti'nden Dâhiliye Nezareti'ne gönderilen 6 Teşrinievvel1327/19 Ekim 1911 tarihli tahrirat: BOA, Dâhiliye Siyasi, Nu. 75-15/1-21. 
önemli bir devlet haline getirmek isteyen Elefterios Venizelos, ${ }^{9}$ başbakanlığa geçmeden önce, gizlice papaz kıyafeti giyerek Girit'ten İstanbul'a geldi. Fener'de bir Rum'un evinde kalan Venizelos Patrikhaneye yeni talimatlar verdi. ${ }^{10}$ Bundan sonra artık Patrikhane, Venizelos'un ve Yunanistan'ın Türkiye'deki icra vasıtası haline gelmiştir. Tarih boyunca toprak isteklerini destekleme konusunda dini, politik bir silah olarak kullanmış ve ondan büyük ölçüde yararlanmış olan Yunanistan, böylece dışarıda Patrikhane gibi önemli bir kuruluşun tekrar desteğini kazanmıştır. ${ }^{11} 1910$ 'da askeri darbe ile başbakan olduktan sonra, Rusların Pan-Slavist propagandalarından da etkilenerek Balkan Devletleri ile ikili anlaşmalar yapmak suretiyle Balkanlardaki Türk varlığına son vermek ve Megali İdea'yı gerçekleştirmek istiyordu. Bu işe, Patrikhane yoluyla girişti. Patrik önce Rum ve Bulgar Milletvekillerinin anlaşmalarını sağladı. 1911'de Sırp Kralı Pierre İstanbul'da Patrik ile Yunanistan'la birleşme konusunu görüştü. İtalyanların Trablusgarp'e asker çıkarması üzerine, 17 Ekim 1912'de Yunanlılar, Sırplar ve Bulgarlar koordineli bir şekilde hep birlikte saldırarak Türk Kuvvetlerini Çatalca'ya kadar sürmüşlerdir. Bu savaş sırasında Patrikhane de Makedonya, Teselya ve Epir'deki Rumları kiliseler vasıtasıyla Osmanlı'ya karşı kışkırtmıştır. Yunan ve Bulgar ordularının Edirne'yi alıp Çatalca'ya doğru ilerlemesi üzerine Rum Patrikhanesi, o bölgede bulunan Rum Metropolit ve Papazlarına Yunan askerleri geldikçe karargahlarına gidip kendilerini takdis etmelerini emretmiştir. Edirne Metropoliti Polikaryos, Trakya'da bulunan papazları da yanına alarak Atina'ya kadar gitmiş ve orada Venizelos'la uygulanacak hareket tarzları hakkında görüşmelerde bulunmuş ve ona uzun ömürler dilemiştir. ${ }^{12}$ Patrik III. Yovakim Avrupa Devletlerinin dikkatini çekmek maksadıyla, Türk Milleti'nin Balkan Savaşları'nın 1stırabı ile kıvrandığı bir dönemde 1912 yılında ölümünden kısa bir süre önce Le Figaro Gazetesi'nin İstanbul muhabirine; "Ben çaresiz bir ruhbandan başka bir şey değilim. Esir bir koyun sürüsünün zavall çobanıyım. Cismanî hiçbir iktidarım yoktur. Canım ve makamım tehlike altındadır. Irkdaş ve mezhepdaşlarım korku içindedirler. Benden öncekilerin neler çektiklerini bütün dünya biliyor. Ancak bütün bunlara rağmen ümitli olmallyız. Seleflerimizin mezara yaklaşırken yaptıkları nasihatler, dinîmizin tebliğine aitti. Ben gelecekten eminim. Ben bir fikir ve gayeyi temsil ediyorum. İste maddî aczime rağmen, bana kuvvet veren bu fikirdir. Bu fikir de er geç bize yapılan zulme rağmen gerçekleşecektir. Bu fikre hiçbir şey karşı gelemez. Bu

${ }^{9}$ Adnan Sofuoğlu, Fener Rum Patrikhanesi ve Siyasi Faaliyetleri, Turan Yayınc1lık, İstanbul, 1996, s.71.

${ }^{10}$ Uğur Yıldırım, Keşiş Güç Emperyalizmin Ortodoks Kartı, 1.Baskı, Otopsi Yayınları, 2005, s.73.

${ }^{11}$ Sula Bozis, "Yoakimyon Rum Kiz Lisesi”, Dünden Bugüne İstanbul Ansiklopedisi, C.3, İstanbul, 1993.

${ }_{12}$ Tuncer Günay, Misyonerler ve Fener Rum Patrikhanesi Haçllların Ajan-Provokatör Kolları, Berikan Yayınevi, Ankara, 2002, s.235. 


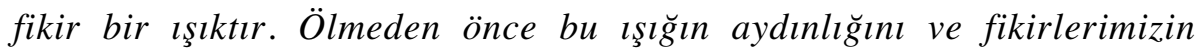
gerçekleştiğini görürsem kendimi bahtiyar hissedeceğim." diyerek, Patrikhanenin gerçek niyetini ortaya koymuştur. ${ }^{13}$

Kısa bir süre sonra Yunanlılar Selanik'i; Sırplar Manastır ve Makedonya'yı, Bulgarlar Edirne ve Kırklareli'ni aldılar. İstanbul hariç, Türklerin Avrupa'daki varlığı sona ermiştir. Osmanlı'dan aldıkları toprakları paylaşamayan Balkan Devletleri bu sefer kendi aralarında II. Balkan Savaşı'nı başlattılar. Bu fırsattan istifade eden Türk kuvvetleri Edirne ve Kırklareli'ni geri almıştır. Balkan savaşları tarihte Osmanlı'nın en büyük toprak kayıplarından birine sebep olmuştur. Rumeli ve Balkanların Türklerin elinden çıkmasında Patrikhanenin payı büyüktür. ${ }^{14}$ Trakya, Makedonya ve Epir'den 200 binden fazla Türk göç etmiştir. Bu durum Osmanlı Devleti'nde tepkiler doğurmuştur. Yunan Hükûmeti karşılıklı bu tehcir işini durdurmak için, o sırada tek başına bir savaşı da göze alamayınca, iki ülke arasında bir nüfus mübadelesi yapılmasını teklif etmiştir. 1 Temmuz 1914'de Makedonya'da kalan Türklerle Doğu Trakya ve Aydın vilayetlerindeki Rumların karşılıklı olarak ihtiyari bir şekilde mübadelesi hususunda anlaşmaya varılmış olmasına rağmen, I. Dünya Savaşı'nın çıkması nedeniyle uygulanma fırsatı bulunamamıştır. ${ }^{15}$

\section{Girit İsyanı ve Ada'nın Yunanistan'a Katılmasında Patrikhanenin Faaliyetleri}

Megali İdea'yı gerçekleştirmek maksadıyla, 1814'de Odesa'da Filiki Eterya (Dostluk Cemiyeti) kuruldu. Cemiyetin arkasında Rus Çarı bulunuyordu. Yunan İsyanını hazırlayan Filiki Eterya, Patrikhaneyi bir silah deposu haline getirerek ellerinde Yunan ve Bizans bayrakları olduğu halde bizzat isyanda ön saflarda görev yapan Patrikhane üyelerinin ve kilise papazlarının da desteği ile 1830 yılında bağımsız bir devlet kurmayı başarmış ve artık Filiki Eterya görevini tamamlamıştır. Ancak, Mora'da bağımsız bir Yunan Devleti kurulması Rumları tatmin etmemişti. Bu sefer 1894'te Atina'da kurulan Etniki Eterya (Millî Cemiyet) görevi üstlendi. Hedef aynı idi. Büyük ideali gerçekleştirmek. ${ }^{16}$ Osmanlı Devleti'nin birçok yerinde olduğu gibi, Girit adasında da Cemiyetin şubesi kuruldu. Yunan ayaklanması ve Balkan Savaşları'na kadar her türlü fesadı tezgâhlayan Fener Patrikhanesi, Cemiyetin ajanları ile işbirliği yaparak Ada'ya çok sayıda silah ve cephane çıkarmışlardır. Yunanlılar ve papazlar tarafından silahlandırılarak Atina Kilisesi ve Fener Patrikhanesinin aralıksız tahrikleri sonucu isyana teşvik edilen eşkıya Ada'daki Türklere saldırıyor, yer yer

\footnotetext{
${ }^{13}$ Osman Ergin, Türkiye'de Şehirciliğin Tarihî İnkişafi, İstanbul, 1936, s. 9. s. 150 .

${ }^{14}$ M. Süreyya Şahin, Fener Patrikhanesi ve Türkiye, Ötüken Neşriyat, İ́stanbul, 1980,

${ }^{15}$ Tevfik Bıyıkoğlu, Trakya'da Millî Mücadele, C.I, Ankara, 1987, s.92-93.

${ }^{16}$ E. Yalçın, Atatürk Türkiye'sinde Ekümenik Ortodoks Patrikhanesi ..., s.41.
} 
isyanlar çıkarıyordu. Nitekim Heybeliada Papaz Okulu mezunlarından Retimo Piskoposu Diyonitos'un önderliğinde, Papaz Sofyanos ve diğer Ruhani liderler, tüm dini görevlerini bir kenara birakarak Patrikhane ile el ele vermek suretiyle Girit İsyanı'nı başlattılar. Patrikhane ve Osmanlı Rumları asileri büyük ölçüde desteklediler. Bu destek maddi ve manevi olmaktan öte, sık sık gönüllü olarak isyana katılıp ön saflarda yerini almıştır. Patrikhane hem isyanı organize ve idare ediyor hem de kiliseler ve halktan topladığı yardımları ve temin ettiği silah ve cephaneyi Ada'ya sevk ediyordu. İsyan böyle uzayıp giderken Avrupalı Devletler araya girerek 28 Kasım 1897'de Girit'e özerklik verildi. 1901'de bir anayasa hazırlayarak bağımsızlığını ilan eden Girit Genel Meclisi, 6 Ekim 1908'de Atina'nın tahrikleriyle, Ada'nın Yunanistan'a bağlanmasına karar verdi. Rahip Fatios'dan bu haberi öğrenen Rumlar toplanarak Türklere küfürler ederek, Türk bayrağını yerlerde sürükleyerek tahriklerde bulundular. Balkan Savaşları'nda yenik düşen Osmanlı, 30 Mayıs 1913'te yapılan Londra Antlaşması ile Girit üzerindeki haklarından vazgeçmiş ve 29 Eylül 1913'te imzalanan İstanbul Antlaşması ile Girit'in Yunanistan'a bağlanmasını resmen kabul etmiştir. ${ }^{17}$

\section{Birinci Dünya Savaşı'nda Patrikhanenin Faaliyetleri}

\section{a. Patrikhanenin kendisini Yunanistan'a bağlama teşebbüsü}

Gayrimüslimlerin büyük bir kısmı ve özellikle Rumlar I. Dünya Savaşı yıllarında, düşman devletler lehine olmak üzere, Osmanlı Devleti'nin savaş gücünü kırmak amacıyla casusluk, propaganda, sabotaj, tahrik, vahşet vs. faaliyetlerini artırdılar. Çok sayıda Gayrimüslimin, Osmanlı Devleti aleyhine, İtilaf Devletleri temsilcileriyle işbirliği yaptıklarına dair belgeler, başta İngiltere olmak üzere diğer Avrupa Devletleri arşivlerinde de bulunmaktadır. ${ }^{18}$ Bunlarla ilgili bilgiler Osmanlı belgelerinde de mevcuttur. Bu cümleden olarak Osmanlı ülkesinde varlığını sürdüren Patrikhane, tâbi olduğu devletin uygulamalarını yok sayarak, Kiliseler Kanunu'nu bahane etmiş ve karışıklık çıkarmaya I. Dünya Savaşı'ndan önce başlamıştı. Trablusgarp ve Balkan Savaşları'nın doğurduğu kargaşalık Patrikhaneye neredeyse hangi devletin kurumu olduğunu unutturan bir zemin oluşturmuştu. Bunu fırsat bilen Patrikhane, mensubu olduğu Devleti küçük düşürmek ve milletin genelinde hâkim olan "Osmanlılık" hissini rencide etmekle birlikte özellikle, Devletin aslî unsuru olan Türklerin manevî mukavemetlerini kırmak için değişik yollara başvuruyordu. Bu amaçla her

\footnotetext{
${ }^{17}$ Fahir Armaoğlu, Siyasi Tarih, Ankara, 1975, s.297; M. Süreyya Şahin, Türkiye'deki Patrikhaneler, İlke Yayıncilık, İstanbul, 2003, s.70.

${ }^{18}$ Salâhi R. Sonyel, "Hristiyan Azınlıklar ve Osmanlı İmparatorluğu'nun Son Dönemi", Osmanlı'dan Günümüze Ermeni Sorunu, (Editör: Hasan Celal Güzel), Ankara, 2000, s. 198199.
} 
türlü yolu deneme ve bütün fırsatları değerlendirme hususunda kararlıydı. ${ }^{19}$ Osmanlı Devleti tarafından kendilerine tanınan birtakım imtiyazlara rağmen, gerek Fener Rum Patrikhanesi gerekse Osmanlı tebaası olan Rumlar, İstanbul'un Türklerin elinden alınması ve Bizans İmparatorluğu'nun ihyası gibi hayalleri o günden itibaren kurmaya başlamış ve yıllarca bu hayal peşinde koşmuştur. Bu düşüncenin itirafı 1918 yılında Fener Rum Patrikhanesi'nin resmî yayın aracı Eklisyastiki Alitya'da yapılmış ve "Rumların Wilson Prensiplerine dayanarak 1453 senesi 29 Mayısinda yapılan haksızlığın tamiri yani İstanbul'un Rumlara iadesi" ${ }^{20}$ isteği açıķa dile getirilmiştir.

Rumluğu ön plana çıkarmak isteyen Patrikhane, fazla dikkat çekmemek amacıyla doğrudan kendisi olmasa dahi, bağlı cemiyetler ve okullardaki dernekler veya işbirliği içerisinde bulunduğu devletlerin, Türkiye'de bulunan diplomatik görevlileri vasıtasıyla oluşturma gayretindeydi. Bu cümleden olmak üzere Tepebaşı tiyatrosunda düzenlenen bir baloda, hiç gereği yokken, Yunan millî marşı çalındı. Bu tür uygulamalar yanlış olduğu halde Balkan Savaşları sırasında da sık sık tekrarlanmıştı. Her sene Tatavla (Kurtuluş)'da Rus Sefiri'nin himayelerinde tertip edilen baloda da benzer durumlar meydana geliyordu. Ancak Tepebaşı tiyatrosunda yapılan baloda durum farklıydı. Yunan Sefiri'nin himayesinde düzenlenmeyen ve sefirin katılmadığı bir baloda Yunan millî marşının çalınmaması gerekirdi. Zira böyle bir uygulama tamamen teamüllere aykırı idi. Benzer bir durum da Pangaltı'nda Osmanlı Rum Mektepleri yararına düzenlenen baloda gerçekleşti. Balo sırasında Osmanlı millî marşından sonra hemen Yunan millî marşı da çalındı. Burada da Yunan Sefiri bulunmadığı halde aynı yanlış hareket tekrarlandığından, baloda görevli Maarif Vekâleti'nden bir yetkilinin uyarıları üzerine balo tertip heyeti özür diledi. Bu gibi hareketler, kasıtlı olarak Yunanlılık şuurunun canlı tutulması için yapılıyor ve aynı zamanda Yunanistan'a olan bağlılıklarını açıkça ortaya koyarak sadakat mesajlarını da göndermiş oluyorlard1. ${ }^{21}$

Patrikhane bir taraftan Rumluk ve Yunanlılık fikrini canlı tutmaya gayret ederken, diğer taraftan da bu fikirlerin hedeflerine ulaşması amacıyla çalışacak Rumların lehine çaba sarf etmekteydi. Bunun için Hükûmet nezdinde teşebbüslerde bulunarak, Rum mahkûmların serbest bırakılmalarını istedi. Patrikhanenin bırakılmasını istediği mahkûmlar arasında; Meis Adası'nın Yunanistan'a ilhakı için Yunan çetelerine yardım ve yataklık yaptıkları sabit olup, cezaları henüz kesinleşmeyen ve mahkemeleri devam

\footnotetext{
s.84.

${ }^{19}$ B. Atalay, Fener Rum Ortodoks Patrikhanesi'nin Siyasi Faaliyetleri (1908-1923),

${ }^{20}$ Ati, 21 Teşrin-i Sâni 1334 (21 Kasım 1918).

${ }^{21}$ İstanbul Vilâyeti'nden Dâhiliye Nezareti'ne gönderilen 16 Şubat 1329/1 Mart 1914 tarihli takrir: BOA, Dâhiliye Kalem-i Mahsus, Nu. 16/31.
} 
eden ve hatta aralarında doğrudan doğruya ayrılıkçı hareket içerisinde bulunan Rumlar da vardı. ${ }^{22}$ Görüldüğü üzere Fener Rum Patrikhanesi Osmanlı Devleti aleyhinde başlatılan ayaklanmalara destek vermiş ve suçu tespit edilenler devlet tarafından ağır bir şekilde cezalandırılmaktan kurtulamamıştır. Genel olarak bu düşüncede olan Fener Rum Patrikhanesi, Birinci Dünya Savaşı ve sonrasında bu politikasını Osmanlı Devleti'ne karşı düşmanca bir harekete dönüştürmüş ve Bizans'ın yeniden kurulması yönündeki faaliyetlerini artırarak sürdürmüştür. Mütareke dönemi incelendiğinde bu tespitin ne derece doğru olduğu açikça görülecektir.

Ayrıca Patrikhane, her zaman olduğu gibi propaganda faaliyetleriyle Avrupa kamuoyunu etkilemeye devam ediyordu. Son zamanlarda bu propagandanın çok arttığını gören Almanya Hariciye Nezareti, Babıâli'nin nazik bir şekilde dikkatini çekti ve bu konuda daha hassas olunması hususunda müstakbel müttefikini uyardı. Bu durumun zaten farkında olan Hükûmet, konu ile ilgili hassasiyetini artırmasına rağmen, şayiaların önüne geçemiyordu. Yunan Sefareti'nin iddiasına göre; Çorlu Kaymakamı yanına aldığı 40 jandarma ile Ereğli Rumlarını göçe zorlamış ve bunların ayni ve nakdî bütün mal varlıklarını ellerinden almıştır. Babıâli, Alman Hariciye Nezareti'nin iyi niyetle yaptığı uyarıları da göz önünde bulundurmuş olmalı ki aleyhine kullanılabilecek her türlü söylentiyi önlemek amacıyla hemen harekete geçmiş̧ir. Edirne Valiliği'nin konu ile ilgili yaptığı incelemede; Çorlu Kaymakamı'nın Ereğli Rumlarını göçe zorlamadığg, bu durumun Devletin aleyhine kullanılmasına fırsat vermemek için Rumlara göç etmemeleri doğrultusunda nasihat ettiği ve bu amaçla gittiğinden dolayı da yanında 40 değil sadece bir jandarma bulunduğu, gasp ve irtikâbın ise hiç söz konusu olmadığı belirlenmiştir. ${ }^{23}$

Milletlerarası platformda Patrikhanenin istismarına firsat vermemek için Babıâli'nin oldukça hassas davranmasına rağmen, Avrupa devletlerinin Adalar Meselesi'nde Osmanlı Devleti aleyhine karar vermeleri bir takım problemleri de beraberinde getirdi. Yunanistan'a geçen adaların karşısında bulunan Anadolu kıyılarında ve daha iç kısımlarda oturan maddî ve manevî yönden kuvvetli Rumlar, Yunanistan'ın ve Patrikhanenin de kışkırtmalarıyla rahat durmayacaktı. Her iki kıyıdan gelip gitme sırasında Megali İdea için hem fikrî zemin, hem de bu fikirleri hayata geçirmeye çalışacak maddî destekler sağlanacaktı. Bu da tabii olarak Yunanistan ile Patrikhanenin üzerinde barındığı toprakların bütünleştirilme sürecini hızlandıracaktı. Bundan başka Adalar Meselesi'nin, Yunanistan lehine hallinden sonra, Makedonya Rumları baskı ve zulümlerini artırdılar. Buralarda yaşayan

${ }^{22}$ Konya Vilâyeti'nden Dâhiliye Nezareti'ne gönderilen 6 Mart 1330/19 Mart 1914 tarihli tahrirat: BOA, Dâhiliye Kalem-i Mahsus, Nu. 14/33.

${ }^{23}$ Edirne Vilâyeti'nden Dahiliye Nezareti'ne gönderilen 13 Teşrinievvel 1330/26 Aralık 1914 tarihli tahrirat: BOA, Dahiliye Kalem-i Mahsus, Nu. 19/76. 
Türkler, Türkiye'ye doğru göç etmeye mecbur edildiler. Türklere uygulanan bu baskıya karşılık, resmen olmasa da gayri resmî olarak, en azından idarecilerin görmezden gelmeleri ve Türklerin biraz daha şuurlu hareket etmesiyle, Türkiye'de yaşayan Rumlar da, Yunanistan'a doğru göçe zorlandı. ${ }^{24}$ Devlet görevlileri resmen bu işe karışmadılar. Buna rağmen fazla bir kargaşa yaşanmadan 100 bine yakın Rum, Yunanistan'a göç etti. Yunanistan beklemediği bu hareket karşısında, Osmanlı Devleti'ni protesto etti. ${ }^{25}$ Buna bağlı olarak olaylar, Babıâli'nin de içinden çıkmakta oldukça zorlandığ 1 bir şekilde gelişmeye başladı. Şöyle ki; Sultan Reşad, Meclis-i Mebusan'1, yenilenmesi amacıyla 18 Nisan 1912 tarihinde feshetmişti. Babıâli'nin de Rumlar ve Patrikhane ile arası iyi olmadığından seçim tarihi bir türlü belirlenememişti. Çünkü yukarıda da belirtmeye çalıştığımız gibi, Yunanistan'ın Makedonya'daki Müslümanları göçe zorlamasına karşı misilleme olarak, bazı Rumlar göçe zorlanıyor veya doğrudan doğruya sınır dişı ediliyordu. ${ }^{26}$

\section{b. Ticari Boykot ve Seçim}

Osmanlı Rumlarını ve Yunan Hükûmeti'ni son derece kızdıran bir olay da başta İstanbul olmak üzere özellikle büyük şehirlerde yaşayan Rumlara ticarî boykot da uygulanarak Yunanistan'a gitmeye mecbur birakılmak istenmesidir. Osmanlı devrinde ekonomik hayata -Türklerin askerlikle meşguliyeti ve devlet dairelerinde çalışmaları sebebiyle-tamamıla Türk olmayan unsurlar egemendi. Rumlar ise en iyi durumda olanla idi. El altından da olsa Hükûmet ve İttihat Terakki tarafından desteklenen Osmanlı ülkesindeki Rumlarla alış veriş yapmamak kararı, bir yandan bunların varlığını baltalamak, öbür yandan da Türklerin ekonomik hayatta yer edinmeleri ve pek zayıf olan durumlarını geliştirmeleri işini kolaylaştırmak amacını güdüyordu. Ancak Osmanlı idaresinde hemen her tedbir aksi sonuçlar doğurduğu için, bu boykot işi de Türklerin ekonomik hayattaki mevkilerini yükseltmekten çok bazı zorbalara muvakkaten servet kazandırmaya yarayacaktır. ${ }^{27}$

Fener Patrikhanesi bu gayri resmî boykot uygulamasına, seçimlerin gündeme gelmesiyle birlikte karşı bir boykotla cevap verme fırsatını elde etti. Patrik V. Yermanos bütün Rumları, Meclis-i Mebusan seçimlerini boykot etmeye çağırarak, bundan kendilerine karşı uygulanan boykotun kaldırılmasıyla vazgeçebileceklerini belirtti. Babıali, Rumlar seçimlere

\footnotetext{
${ }^{24}$ Yusuf Hikmet Bayur, Türk Inkılabı Tarihi, Cilt:II/III, Türk Tarih Kurumu Yayınları, Ankara, 1983, s. 251.

${ }^{25}$ Halil Menteșe, Anılar, İstanbul, 1986, s. 118. s.87.

${ }^{26}$ B. Atalay, Fener Rum Ortodoks Patrikhanesi'nin Siyasi Faaliyetleri (1908-1923),

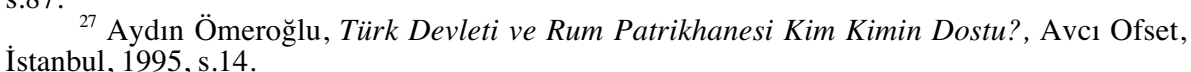


katılmadı̆̆ 1 takdirde, Avrupa'da Osmanlı Devleti aleyhine olan durumun daha da kötüleşebileceği endişesini taşıdığından, boykotta kendilerinin dahli olmadığını, hiç kimsenin boykota zorlanamayacağını ve buna tevessül edenlerin cezasız kalmayacağını belirtti. Hükûmetin bu açıklamalarından sonra Patrikhane, 1914 Ocak ayı sonunda Rumların seçimlere katılmasına karar verdi. Patrikhane bu kararı almasına rağmen bazı hususlarda endişeliydi. Çünkü Patrikhane, kendisine bağlı Rum seçim heyetinin göstereceği adayların İttihat ve Terakki tarafından seçtirilmesini istiyordu. İttihat ve Terakki ise, "Osmanlılık" duygularını incitmemiş, sicili temiz ve Türkçe konuşup, yazabilme şartlarını arıyordu. (Bu şartları taşımak zaten anayasa gereği idi.) Bir diğer anlaşmazlık ise milletvekili sayısı üzerinde idi. İttihat ve Terakki 14-15, Patrikhane ise 20 kişilik bir kontenjanda 1 srar etmekteydiler. Nihayet taraflar arasında 1914 yılının Şubat ayında, milletvekili sayısının 17 veya 19 olması ve İstanbul'dan seçilecek üç Rum Mebus için Patrikhanenin altı aday göstermesi hususunda anlaşmaya varıldı. ${ }^{28}$ Seçim yapıldıktan sonra 14 Mayıs 1914 tarihinde Meclis-i Mebusan açıldı. Patrikhane bazı yerlerde seçime itiraz etmesine rağmen, ${ }^{29} 1914$ seçimlerinden kazançlı bir şekilde çıktı. ${ }^{30}$

Patrik V. Yermanos başkanlığında bir heyet, Adliye Nazırı'nı ziyaret ederek boykotun kaldırılmasını istedi. Bu hareket Avrupa devletlerinin dikkatini çekmek için her zaman başvurdukları sıradan bir hareketten başka bir şey değildi. Ancak Adliye Nazırı, boykotta Babıâli'nin etkisinin olmadığını, Rum esnaf ve tüccardan mal satın alınmamasının bazı vatandaşlar tarafından yapılan şahsi bir tercih olduğunu belirtti. Patrik, Nazır'a Avrupa devletlerine şikâyet edeceklerine dair ağır bir dille yazılmış muhtıra vermek istedi. ${ }^{31}$ Fakat bu muhtıra kabul edilmedi. Patriğin, muhtıra vermeye çalıştığı günlerde Yunan meclisinde de aynı mesele ele alınıyordu. Daha sonra Patrik, Mayıs 1914'de Padişaha muzdarip oldukları noktaları belirten bir dilekçe verdi. Beklediği gelişmeleri göremeyen Patrik, Rum kilise ve okullarını görünüşte matem ve protesto amacıyla, gerçekte Avrupa kamuoyunun dikkatini çekmek için kapattırd.. ${ }^{32}$ Rum okullar da iş yapmayarak bir tür grev yaptılar. Maddî sıkıntıya düşen Rumların göçünü engellemek için yoğun bir çaba sarf eden Patrik V. Yermanos, Rum Muhtarlar üzerinde baskı kurarak, "Ferağ ve İntikal ilmühaberleri"ni, ${ }^{33}$ tasdik etmemelerini istedi. Bunun üzerine Babıâli muhtarlara, Patrikhanenin böyle

\footnotetext{
${ }^{28}$ Y. H. Bayur, 1983, Türk Inkılabı Tarihi, s. 274-275.

${ }^{29}$ İhsan Güneş, Türk Parlamento Tarihi, I, Ankara, 1995, s. 269.

${ }^{30}$ B. Atalay, Fener Rum Ortodoks Patrikhanesi'nin Siyasi Faaliyetleri (1908-1923), s.88.

${ }^{31}$ Hüseyin Kâzım Kadri, Rum Patriğine Açık Mektup, İstanbul, 1330, s. 4.

${ }^{32}$ Y.H.Bayur, 1983, Türk İnkılâbı Tarihi, Ill/III, s. 254.

${ }^{33}$ Ferağ ve İntikal ilmühaberi: Bir kimsenin gayrimenkuldeki tasarruf hakkım bedeli karşılığında terk ettiğini gösterir resmî Belge (Mehmet Zeki Pakalın, "Piskopos Mukataa Kalemi", Osmanlı Tarih Deyimleri ve Terimleri Sözlü̈̆̈̈̈, II, İstanbul, 1993, s. 602).
} 
bir emir vermeye yetkisi olmadığını belirterek görevlerini yapmaları hususunda uyardı. Bu gergin vaziyet savas süresince devam etmiştir. Fener Patrikhanesi, Rum Muhtarlar üzerinde tam olarak etkili olamayınca, Yunanistan'a Rum göçünü engellemek için özellikle Edirne, Kırkkilise (Kırklareli), Çatalca ve Vize havalisinde görev yapmaları için metropolit ve papazlardan nasihat heyeti oluşturdu. Patrikhanenin isteği üzerine, bu heyete gittikleri yerlerde kolaylık gösterilmesi için Hükûmet tarafından taşra idarecilerine talimat verildi. ${ }^{34}$

Türkiye'den Yunanistan'a olan Rum göçünün önüne geçilemiyordu. Zira göçün temel sebeplerinden olan boykot fiilen artarak devam ediyordu. Çünkü Türk milliyetçiliği beraberinde ticaret, endüstri ve şehircilikte Türkleşmeyi de getirmekteydi. Türk ticarî grubu oluştukça ve güçlendikçe Rumlara karşı ekonomik boykot arttı. Bunun tabii sonucu olarak da geçmiş yıllara göre Rumlar, özellikle ticarî hayattan dışlanmaya başladılar. ${ }^{35}$ Ayrıca İttihat ve Terakki Hükûmeti, 5 Eylül 1914 tarihinde kapitülasyonları kaldırarak, iktisadî Türkçülüğü de öne çıkarmayı ve Türk kapitalist grubunun alt yapısını oluşturmayı hedefliyordu. ${ }^{36}$ Rum ve Yunanlılara karşı uygulanan boykot Türk Millî Mücadelesi'nin arifesine kadar devam etti. Rumlar, Türkçe gazetelerin boykotu kışkırttı̆̆ını düşünürken, Rumca gazetelerin yaptıklarını görmezden geliyorlard.$^{37} \mathrm{Bu}$ arada Rum tüccarlar Yunanistan'daki temsilcilerini ikinci bir emre kadar mal göndermemeleri için uyardılar. Bununla amaçları piyasayı daraltarak, halkı kendi mallarını almaya mecbur bırakmaktı. ${ }^{38}$ I. Dünya savaşı sonunda ve Kurtuluş Savaşı yıllarında İstanbul'daki Rum basını da Patrikhane'nin teşvikiyle kışkırtıcı yayınlar yapıyordu. Bunlardan Patrikhane'nin resmî gazetesi olan Eklisiyartiki Alitia'da şöyle yazılar yazılacak kadar ileri gidildi. ${ }^{39}$ “....Bir milletin, müsavat vaitleriyle ĭgfal edildiği zamanlar geçmiştir. Bu devlet yıkllıyor. Bu köhne hayide vaitlerle devlet toplanamayacaktır. Coğrafi istatistikler serdi ve Türk unsurunun ekseriyeti haiz olduğuna ve bununla beraber Rum milletinin de böyle batıl tarz-ı tesviyelerle idare-i maslahat edilmesi lazım geldiğine kimseyi ikna edemez. Haritaları tertip edenler unutmamalıdır ki Rum unsuru bir çok yerlerde ekalliyette ise baba mirası üzerindeki tarihî ve sosyal hukukunu kaybedemez." Burada "baba mirası" dediği Bizans'tan kalma topraklardır. Hâlbuki bir yerin mirası "baba mirası" ya da "dede mirası" ile ölçülmez. O yerin o anda sahip olduğu çehre ile ölçülür. ${ }^{40}$ Bilindiği gibi, Balkan Savaşları’nı Birinci Dünya Savaşı izledi.

${ }^{34}$ Adliye ve Mezâhib Nezareti'nden Dâhiliye Nezareti'ne gönderilen 21 Cemaziyülevvel 1332/17 Mayıs 1914 tarihli tahrirat: BOA, Dâhiliye Kalem-i Mahsus, Nu. 19/45.

${ }_{35}$ A. Alexandris, The Greek Minority of Istanbul and Greek-Turkish Relitions..., s. 44.

${ }^{36}$ Sina Akşin, Jön Türkler ve İttihat ve Terakki, İstanbul, 1987, s. 276-277.

${ }^{37}$ Sabah, 17 Teşrinievvel 1334/17 Ekim 1918.

${ }^{38}$ Türkçe İstanbul, 26 Mart 1335/1919.

${ }^{39}$ Akşam, No:46, 4 Teşrinisani 1334/Kasım 1918.

${ }^{40}$ E. Yalçın, Atatürk Türkiye'sinde Ekümenik Ortodoks Patrikhanesi..., s.94. 
Savaşta Osmanlı Devleti yenildi. Bu yenilgi, yarı sömürge haline gelmiş olan Osmanlı İmparatorluğu'nun tamamen çökmesine neden oldu. İmparatorluğun çöküşü, Yunanistan'1 ve Rum Patrikhanesi'ni “Megali İdea" y1 gerçekleştirme çalışmalarında daha da cesaretlendirip ümitlendirdi. Çünkü artık zaman gelmişti. Bu inançla Yunanistan, Rumlar ve Rum Patrikhanesi Osmanlı Devletine karşı açıktan açığa düşmanca faaliyetlere girişti. Fransa ve İngiltere de yine yanlarında idi. ${ }^{41}$

\section{c. Hukûk-ı Aile Kararnâmesi ve Patrikhane}

Bütün hukukî meselelerde olduğu gibi, Rumlarda aile hukukunda da söz sahibi olan kurum Patrikhane idi. Tanzimat Fermanı ile başlayan ve sonra devam eden kanunlaştırma hareketleri Patrikhanenin yetki alanını daralttı. ${ }^{42} \mathrm{Bu}$ süreçte tedricen Patrikhanenin yetkileri günün şartları içerisinde yasalara uygun olarak Devletin başka kurumlarına verilmeye başlandı. Patrikhane bu değişikliklere karşı çıktı ve bundan dolayı birçok patrik, kadim imtiyazları ellerinden alındığı iddiasıyla istifa etti. Bütün baskılara rağmen Babıâli hukuk birliğinin sağlanmasında kararlıydı. Çünkü çok hukukluluk değişen şartlar içerisinde Devletin varlı̆̆ını tehdit ediyordu. Millet sistemi içerisinde benliklerini muhafaza eden unsurlar, Fransız ihtilalinden sonra hızla milletleşme sürecine girdiler. Osmanlı Devleti, tabiiyetinde olanların birliği ve beraberliği üzerinde hassasiyetle duruyor ve bunları "Tebaa-i Devlet-i Osmaniye" yani "Osmanlı Vatandaşı" kavramıyla bir arada tutmak istiyordu. Bu amaçla 19 Şubat 1869 tarihinde "Tabiiyet-i Osmaniye Kanunnamesi" çıkartıldı. ${ }^{43}$ Çıkartılan yeni kanuna rağmen, Avrupa Devletleri, kapitülasyonları gerekçe göstererek Gayrimüslimlerin haklarının ihlâlini ileri sürüyor ve Osmanlı Devleti'nin içişlerine müdahaleye devam ediyorlardı. Bu müdahalelere engel olmak ve cemaatler üzerinde denetimini devam ettirmek isteyen Babıâli, "Tabiiyet-i Osmaniye Kanunnamesi"ni de yeterli görmediği için 10 yıllık bir çalışma sonunda, 1878 yılında "Mecelle"yi hazırlattı. Böylece hukuk birliğinin sağlanması hususunda çok önemli bir mesafe kat edilmiş oldu. ${ }^{44}$

Cemaat üzerindeki etki ve denetiminin azalarak istediği gibi yönlendiremeyeceği endişesiyle Patrikhane, Mecelle'nin uygulanmasına da karşı çıktı. Babıâli ise hukuk birliğiyle tebaasını tam anlamıyla "Osmanlı Vatandaşı" statüsüne kavuşturmak istiyordu. Böylece tebaa arasındaki farklı uygulamaların sakıncalarından doğan meseleler ortadan kalkarken, aynı zamanda da Ortodoksların ve özellikle Rumların, Patrikhane tarafından

${ }^{41}$ Nail Arslanpay, Diyanet İşleri Başkanlığı Yayınları, Ankara, 1973, s.6.

42 Athanasia Anagnostopulu, "Tanzimat ve Rum Milletinin Kurumsal Çerçevesi Patrikhane, Cemaat Kurumları, Eğitim" 19. Yüzyll İstanbul'unda Gayrimüslimler, (Ẻditör: Pinnelopi Stathis), (Çev. Foti ve Stefo Benlisoy), İstanbul, 1999, s. 12-13.

${ }^{43}$ Düstur, I/I, s. 16-18.

${ }^{44}$ Cevdet Paşa, Maruzat, (Yay. Yusuf Halâçoğlu), İstanbul 1980, s. 206. 
ayrılıkçı oluşumlar içerisinde kullanılmaları engellenmiş olacaktı. Özellikle kapitülasyonlardan dolayı Devletin hâkim güç olarak kendi tebaası ya da vatandaşı üzerinde nüfuzunu tesis etmesi çok zordu. Bunlara ilave olarak, Osmanlı ülkesinde yaşayan Avrupa Devletleri vatandaşlarıyla ilgili belirsizlik de bu durumu tamamen içinden çıkılmaz bir hale getiriyordu. Yapılmaya çalışılan düzenlemelerle vatandaşlık esasına dayanan hukuk birliğine doğru önemli bir adım atılmış oldu. ${ }^{45}$

Osmanlı Devleti, yıllardır istismar edilen kapitülasyonların kıskacından kendisini kurtarmak için 5 Eylül 1914 tarihinde kapitülasyonları kaldırmıştı. Buna rağmen arzu edilen noktaya gelinemediği için 1916 yılında yapılan İttihat ve Terakki Kongresinde alınan karara bağlı olarak, Şer'iye Mahkemeleri 25 Mart 1917 tarihinde Adliye ve Mezâhib Nezareti'ne bağlandı. Hukuk-u Aile Kararnamesi de bu sürecin tabii sonucu olarak ortaya çıktı. ${ }^{46}$ Hukuk-u Aile Kararnamesi kapitülasyonlara karşı verilen mücadelenin en önemli safhalarından birisidir. Kararname, Isparta Mebusu Seydişehirli Mahmut Esad Efendi başkanlığında bir heyet tarafından 157 madde olarak hazırlandı ve 25 Ekim 1917 tarihinde Sultan Reşat tarafından onaylanarak yürürlüğe girdi. ${ }^{47} \mathrm{Bu}$ kararname ile hukuk alanında önemli bir adım atılarak çok hukukluluğun sakıncaları ortadan kaldırılmaya çalışıldı. Hukuk-u Aile Kararnamesi ${ }^{48}$ ile asıl gerçekleştirilmek istenilen, başta Gayrimüslimler olmak üzere bütün tebaayı, tam anlamıly vatandaş haline getirmekti. Tebaanın din farklılığı göz önüne alınarak aile hukuku düzenlendi. Bu düzenleme hukuk birliğgine aykırı gibi görünse de bunun ile kanun birliği sağlandı. ${ }^{49}$ Hukuk-u Aile Kararnamesi ile Patriğin yargı yetkisi kaldırılarak, Devlete devredildi. Bunun tabii sonucu olarak, Gayrimüslimleri bahane ederek, Osmanlı Devleti'nin içişlerine müdahale etmeye çalışan devletlere de engel olunacakt1. ${ }^{50}$ Patrikhane, Hukuk-u Aile Kararnamesi'nden çok rahatsız oldu ve buna şiddetle karşı çıkarak, yetkilerinin kendisine iade edilmesini istedi. ${ }^{51}$ Patrik Vekili Dorotheos, Mondros Mütarekesi'nden sonra daha da ileri giderek, Patrikhane için yeni bir nizamnamenin hazırlanmasını istedi. $^{52}$ s.92.

${ }^{45}$ B. Atalay, Fener Rum Ortodoks Patrikhanesi'nin Siyasi Faaliyetleri (1908-1923),

${ }^{46}$ Sina Akşin, Jön Türkler ..., s. 277, 302.

${ }^{47}$ Mehmet Âkif Aydın, İslâm ve Osmanlı Hukuku Araștırmaları, İstanbul, 1999, s. 179.

${ }^{48}$ Hukûk-1 Aile Kararnâmesi'nin maddeleri için bkz. Düstur, IX, "Hukûk-1 Aile Kararnamesi", İstanbul, 1928, s. 762-783.

${ }^{49}$ Taha Akyol, Medine'den Lozan'a, İstanbul, 1997, s. 70.

50 Ali Fuat Türkgeldi, Mesâil-i Mühimme-i Siyasîyye, I, (Yay. Bekir Sitkı Baykal), Ankara, 1987, s. 381 .

${ }_{52}^{51}$ Sabah, 15 Teşrinievvel 1334/15 Ekim 1918.

${ }_{52}$ Sabah, 13 Teşrinisani 1334/13 Kasım 1918. 


\section{d. Batı Trakya ve Oniki Adaların Yunanistan'a katılmasında Patrikhanenin Faaliyetleri}

Balkan Savaşı sonunda Selanik ve Makedonya'nın bir kısmını alıp Karasu'ya dayanan Yunanistan, şimdi de gözünü Batı Trakya'ya çevirmişti. Megali İdea uğrunda yüzyıllarca pusuda beklemesini bilen Rumlar, uygun zamanlarda harekete geçerek paylarına düșeni alıyor ve büyük hedefe doğru adım adım yaklaşıyorlardı. Giritli Elefterios Venizelos, Yunanistan'ı İngiltere ve Fransa yanında savaşa sokarak, kazanılacak zaferden büyük ölçüde yararlanmak istiyordu. Onun "Gençliğimden beri ben Skiros adasını Elenizmin coğrafi merkezi saymışımdır" şeklinde ifade ettiği hayali gerçekleştirebilirdi. Çökmekte olan Osmanlı Devleti'ne karşı Ege'yi bir Yunan denizi haline getirmek, iki kıtaya uzanan ve beş denize açılan Yunanistan'ı gerçekleştirerek, bir ayağı Asya'da, bir ayağı Avrupa'da olacak büyük Yunanistan'1 Bizans-Grek İmparatorluğu'nu yeniden kurmak, bu hayalin sonuçlarıydı. ${ }^{53}$ Nitekim Rauf Orbay hatıralarında Patrikhane'den "nifak ve fesat yuvasi" olarak bahseder. ${ }^{54}$ Patrikhane'nin böyle bir merkez durumuna gelmesinde, burasının Yunanistan'ın Türkiye üzerindeki emellerinin gerçekleştirilmesi yolunda çok uygun bir kuruluş olması başlıca rolü oynamıştır. Çünkü Rum Ortodoks Kilisesi, Yunan tarihinde önemli bir fonksiyona sahipti. İstiklalini kazanan ve bir hayli de genişleyen Yunanistan, hedefine ulaşabilmek için doğudaki büyük Türk potansiyelini yalnız Yunan Kilisesi ile etki altına almanın mümkün olamayacağını uzun bir deneme ile anlamıştır. Bu nedenle, başarılı olabilmek için, daha önce de çok yararlandığı Türk topraklarındaki kiliseleri Türklere karşı tahrik ve baltalama aracı olarak kullanma kararı vermiştir. Bu kararın bir gereği olarak 1908'de II. Meşrutiyet'in ilanı üzerine faaliyetlerini artıran Patrikhane'yi yarı resmî de olsa Yunanistan'la birleştirmeyi birinci gaye olarak almıştı. Bizans'ı ihya etmek, bu hülyayı millî bir siyaset haline getirmek için mutlak surette Fener Patrikhanesi'nin faaliyet ve tahriklerine ihtiyaç vardı. Zira Patrikhanenin daha önceki büyük hizmetleri bilinmekteydi.$^{55}$ Patrikhane'nin Yunanistan emellerine hizmet eden bir kuruluş durumuna gelmesi aslında 1910 yıllarında resmîleşmiş durumda bulunuyordu. Nitekim Yunan Millet Meclisinde 5 Mart 1921 yılında yapılan bir tartışmada, Dışişleri Bakanı Baltacis'in sözlerinden Patrikhane'nin Yunanistan'a nasıl hizmet ettiği çok iyi anlaşılmaktadır. Baltacis, Patrikhane'ye hücumlarda bulunan milletvekili Kampanis'e şöyle cevap vermiştir; "Yunan Milleti bugün Fener Patrikhanesine şükran borçludur. Onun geçmişteki mücadeleleri, Yunan Milletini bu fütuhata nail ettirdi. Sözlerinizi geri alınız...".56 Nihayet, 27

${ }^{53}$ A. Sofuoğlu, Fener Rum Patrikhanesi ve Siyasi Faaliyetleri, s.72.

${ }_{54}^{54}$ Süleyman Hayri Bolay, Felsefi Doktrinler ve Terimler Sözlüğ̈̈̈, Ankara, 1999.

${ }^{55}$ T. Günay, Misyonerler ve Fener Rum Patrikhanesi..., s.232.

${ }^{56}$ Gülnihal Bozkurt, Alman ve İngiliz Belgelerinin ve Siyasi Gelişmelerin Işı̆ğı Altında Gayr-i Müslim Osmanlı Vatandaşlarının Hukuki Durumları (1839-1914), Ankara, 1998, s.56. 
Kasım 1919'da Paris yakınlarındaki Neuilly'de yapılan bir anlaşma ile Batı Trakya da Yunanistan'a verildi. 1944 Ekimi'nde Almanlar geri çekilirken Adaları Türkiye'ye bırakmayı teklif etmişse de, İngilizlerce reddedilmiştir. Savaş sonrası Adalar bir süre müttefik askerlerin elinde kaldı. İtalyanlar yenildiği için sahipsiz kalan Adalara Yunanistan sahiplendi. Müttefikler 1947 'de Paris'te yapılan bir antlaşma ile Adaları Yunanistan'a verdiler. ${ }^{57}$

\section{SONUÇ}

Osmanlı Devleti, bünyesinde çeşitli din ve ırkları barındıran bir imparatorluktu. XIX. Yüzyıldan itibaren Batılı devletler tarafından "Hasta Adam" diye nitelenerek mirasının bölünmesi planlanıyordu. Bu yıkımı hızlandırmak için de devletin içerden de zorlanması gerekiyordu. Bunun yolu ise, Osmanlı topraklarındaki azınlıkları kullanmaktı. Başta büyük devletler olmak üzere dinî yolu kullanarak azınlıkları etkilemek ve onların gücünden istifade etmek istiyorlard.

Osmanlı'nın Bizans'tan devraldı $\breve{g}$ bir kurum olan Patrikhane'nin, Osmanlı'nın siyaseti gereği bazı yetkilerle donatılarak "millet sistemi" esasına dayanan Osmanlı gücünün Patrikler aracılı̆̆ ile Rum tebaa üzerinde etkinleştirildiğini görmekteyiz. Sistemin iyi işlediği Osmanlı'nın güçlü dönemlerinde Patrikhane de kendisine biçilen rolü iyi oynuyordu. Ne var ki, Osmanlı İmparatorluğu'nun gerileme ve çökme dönemlerinde Patrikhane, milliyetçilik akımlarından etkilenerek dış güçlerin desteğini de almak suretiyle, Yunanistan'ın bağımsız bir devlet olma yolunda yürütülen her faaliyetin içerinde olmuş; ya olayı organize etmiş, ya desteklemiş, ya da bizzat icra etmiştir. Megali İdea için çok önemli bir dönüm noktası olan Yunanistan'ın bağımsız bir devlet olma düşüncesini hayata geçirmiş, Bizans'ı yeniden canlandırmak için Balkanlarda yaşayan bütün Ortodoksları Rumlaştırma siyasetine hız vermiştir. Yunanistan, topraklarını genişletme yolunda kısa sürede çok mesafe kat ederek, Patrikhane'nin desteği ile kurulduğu günden I. Dünya Savaşı'nın sonuna kadar topraklarını katlayarak büyütmeyi başarmıştır.

Bir Osmanlı Kurumu olan Patrikhane; Meşrutiyet döneminde ve takip eden süreç içerisinde "Sen Sinod" Meclisi Mukaddes Nizamnamesini ikinci plana bırakarak Osmanlı Hükûmeti'ne karşı herhangi bir sorumluluk duymadan, doğrudan doğruya Yunan Başbakanı Venizelos'un temsilcisi sıfatıyla siyaset sahasındaki etkinliğini artırmıştır. Fırsat buldukça bütün sorumluluğunu unutarak siyasetle uğraşmış, bağlı bulunduğu devlete ihanet etmiştir. Venizelos da, Patrikhanede'ki çalışmalar için hiçbir yardımdan kaçınmamıştır. Patrikhane'nin bu dönemde gösterdiği her türlü faaliyette başlıca rolü oynayan şahıs Patrik Vekili Doroteos Mamelis idi. Doroteos

\footnotetext{
${ }^{57}$ M.S. Şahin, Türkiye'deki Patrikhaneler, 2003, s.72.
} 
gözü pek, azimli ve zeki bir papazdı. Patrikhane'nin imtiyazlarının Jön Türkler tarafından fes edilmesini her şeyden önce Babıâli nezdinde protesto etmiş, Rum çetelerinin bütün faaliyetlerinde bizzat bulunmuştur. Mavri Mira Örgütünün başkanlığını da yapan, 17 Ekim 1919'da Ermeni Patriği Zaven Efendi ile birlikte “bütün Türkiye'nin işgal edilmesini” isteyen, 14 Şubat 1920'de "Lloyd George'a İstanbul için Yunan mandasını" teklif eden de yine Doroteos Mamelis idi.

Patrikhane makamı Bizans'ın dinî ve dünyevi olan iki yönlü iktidarının ayakta kalan tek taraflı devamıdır. Yani Bizans Patrikhane'nin şahsında yaşamaktadır. Bizans'ın sembolü olan çift başlı kartal, bugün Patrikhane'nin simgesi durumundadır. Patrikhane'nin amacı; Megali İdea'yı, büyük Yunanistan hayalini gerçekleştirmek, yani İstanbul başkent olmak üzere Bizans İmparatorluğu'nu yeniden diriltmektir. Zaman içinde Türk Milleti'nin çektiği ıstırap ve sıkıntılarda Patrikhane'nin etkisini ve sonra meydana gelen değişiklikler göz önüne alındığında kısaca şunu belirtmek mümkündür: Fener Patrikhane'si, Türkiye topraklarının köklü bir kurumu olarak, bu topraklar üzerinde hâkim olan Osmanlı Devleti, daha sonra da yine Türk Milleti'nin kurtuluş ve yeni Türk Devleti'nin kuruluş safhası ile birlikte, Türk Milleti'nin ve Devleti'nin düşmanları ile işbirliği içerisinde olmuştur. Fener Patrikhanesi'nin, Türk Devleti güçlü olduğu zaman daha temkinli ve 1lımlı hareket etmesine rağmen, devlet zaafa düştüğünde hiç tereddüt etmeden bütün iç yüzünü ortaya koyduğunu tarihî olaylardan anlamak mümkündür.

\section{KAYNAKÇA}

Akşin, Sina; Jön Türkler ve İttihat ve Terakkî, İstanbul, 1987.

Akyol, Taha; Medine'den Lozan'a, İstanbul, 1997.

Alexandris, Alexis; The Greek Minority of İstanbul and Greek-Turkish Relitions 1918-1974, Athens, 1983.

Anagnostopulu, Athanasia; "Tanzimat ve Rum Milletinin Kurumsal Çerçevesi Patrikhane, Cemaat Kurumlarl, Eğitim" 19. Yüzyıl İstanbul'unda Gayrimüslimler, (Editör: Pinnelopi Stathis), (Çev. Foti ve Stefo Benlisoy), İstanbul, 1999.

Arslanpay, Nail; Diyanet İşleri Başkanlı̆̆ Yayınları, Ankara, 1973.

Atalay, Bülent; Fener Rum Patrikhanesi’nin Siyasî Faaliyetleri (1908-1923), Tarih ve Tabiat Vakfı (TATAV) Yayınları, İstanbul, 2001.

Aydın, Mehmet Âkif; İslâm ve Osmanlı Hukuku Araştırmaları, İstanbul, 1999. 
Bayur, Yusuf Hikmet; Türk İnkılâbı Tarihi, Cilt:I, Kısım:II, Türk Tarih Kurumu Yayınları, Ankara, 1983.

Bolay, Süleyman Hayri; Felsefi Doktrinler ve Terimler Sözlüğü, Ankara, 1999.

Bozis, Sula; "Yoakimyon Rum Kız Lisesi”, Dünden Bugüne İstanbul Ansiklopedisi, C.3, İstanbul, 1993.

Bozkurt, Gülnihal; Alman-İngiliz Belgelerinin ve Siyasî Gelişmelerin Işı̆̆̆ Altında Gayrimüslim Osmanlı Vatandaşların Hukukî Durumu (1839-1914), Ankara, 1996.

Cevdet Paşa, Maruzat, (Yay. Yusuf Halâçoğlu), İstanbul, 1980.

Ercan, H. Yavuz, Ondokuzuncu Yüzyllda Balkanlarda Kilise, Ankara, 1987.

Ergin, Osman; Türk Maarif Tarihi, II, İstanbul, 1940.

Frazee, Chavles A.; The Orthodox Church and Independent Greece 1821-1852, Cambridge, 1969.

Güneş, İhsan; Türk Parlamento Tarihi, I, Ankara, 1995.

Tuncer Günay, Misyonerler ve Fener Rum Patrikhanesi Haçllların Ajan-Provokatör Kolları, Berikan Yayınevi, Ankara, 2002.

Hacettepe Üniversitesi Atatürk İlkeleri ve İnkılap Tarihi Enstitüsü Öğretim Üyeleri, Atatürk ve Türkiye Cumhuriyeti Tarihi, Siyasal Kitabevi, Ankara, 2004.

Kadri, Hüseyin Kâzım; Rum Patriğine Açık Mektup, İstanbul, 1330/1914.

Kâmil Paşa'nın Anıları, (Yay. Gül Çağalı Güven), İstanbul, 1991.

Menteşe, Halil; Anılar, İstanbul, 1986.

Ömeroğlu, Aydın; Türk Devleti ve Rum Patrikhanesi Kim Kimin Dostu?, Avcı Ofset, İstanbul, 1995.

Pakalın, Mehmet Zeki; "Piskopos Mukataa Kalemi", Osmanlı Tarih Deyimleri ve Terimleri Sözlü̆̆̈̈̈, II, İstanbul, 1993.

Sofuoğlu, Adnan; Fener Rum Patrikhanesi ve Siyasi Faaliyetleri, Turan Yayınc1lı, İstanbul, 1996.

Şahin, M. Süreyya; Fener Patrikhanesi ve Türkiye, Ötüken Neşriyat, İstanbul, 1980.

Şahin, M. Süreyya; Türkiye'deki Patrikhaneler, İlke Yayıncllık, İstanbul, 2003.

Sonyel, R. Salâhi; "Hristiyan Azınlıklar ve Osmanlı İmparatorluğu'nun Son Dönemi", Osmanlı'dan Günümüze Ermeni Sorunu, (Editör: Hasan Celal Güzel), Ankara, 2000. 
Türkgeldi, Ali Fuat; Mesâil-i Mühimme-i Siyasîyye, I, (Yay. Bekir S1tkı Baykal), Ankara, 1987.

Yalçın, Emruhan; Atatürk Türkiye'sinde Ekümenik Ortodoks Patrikhanesi ve Bizans Projesi, Siyasal Kitabevi, Ankara, 2008.

Yıldırım, Uğur; Keşiş Güç Emperyalizmin Ortodoks Kartı, 1.Baskı, Otopsi Yayınları, 2005.

BOA (Başbakanlık Osmanlı Arşivi).

Meclis-i Ayan Zabit Ceridesi.

MMZC (Meclis-i Mebusan Zabit Ceridesi).

Düstur, IX, "Hukûk-1 Aile Kararnamesi", İstanbul, 1928.

Akşam, Ati, Sabah, Türkçe İstanbul Gazeteleri. 